UDC 637.12/.13(497.6); 636.2.034

COBISS.SR-ID: 220303116

Original research paper

Acta Agriculturae Serbica, Vol. XX, 40 (2015); 127-135

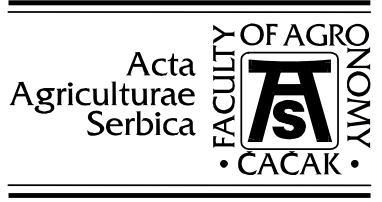

\title{
Analysis of some cattle farms focused on milk production
}

\author{
Tatjana Pandurević ${ }^{1}$, Milica Mojević ${ }^{1}$, Ivan Rankić ${ }^{1}$, \\ Bojana Ristanović ${ }^{2}$ \\ ${ }^{1}$ University of East Sarajevo, Faculty of Agriculture, Vuk Karadzic 30, \\ East Sarajevo, Bosnia and Herzegovina (RS) \\ ${ }^{2}$ University of Priština, Faculty of Agriculture, Lešak, Serbia
}

\begin{abstract}
This study was conducted in the municipalities of Pale and Sokolac on a sample of 30 Simmental and Holstein-Friesian dairy cattle farms. Farm size, land area, number of household members, average milk fat content, protein content and total milk production per dairy cow were analyzed. Slight variations were observed due to the same climatic conditions and the same technology and breeding method used. The slightly higher milk fat percentage in Simmental cows is their breed characteristic.
\end{abstract}

Key words: Simmental, Holstein-Friesian, characteristics of cattle farms.

\section{Introduction}

Cattle breeding and the milk production sector are very important for the satisfaction of human nutrition needs and the production of animal proteins in every country around the world. Cattle production is the most important segment of livestock production i.e. an indicator of the overall development of the

Received: 15 June 2015 / Accepted: 23 November 2015 
agricultural and food sectors in the Republic of Srpska. The value gained from cattle breeding products accounts for more than $40 \%$ of the total agricultural production in the Republic of Srpska. The typical breed used in the cattle production in the Republic of Srpska is the one that has meat-milk and milkmeat production traits combined, whose basis is Simmental breed, whereas in East Herzegovina it is the Gatacko ox, as an indigenous strain of cattle.

Farm structure in the Republic of Srpska is very complex, consisting of small subsistence agricultural households, small semi-subsistence farms, large family farms, and privatized large enterprises with a mixed ownership structure (Bogdanov and Božić, 2010). The main problem in cattle production is insufficient production of milk and meat. The agricultural structure is underdeveloped, farms are very small, with the average of 0.93 ha per farm, in contrast to 18.4 ha in the EU. In European Union countries, attention is focused on production systems and marketing (Gabina, 2006). Special attention is given to new techniques for sustainable production and milk quality (Petrović, 2007).

Lactation, milk yield and milk composition are considered breed traits, regardless of extremes in terms of milk yield and milk composition. In the study area, breed structure is similar to that in the wider area of the Republic of Srpska and Bosnia and Herzegovina. Unfavorable characteristics of milk production in the Republic of Srpska include low milk yield per cow, disadvantaged breed structure and low marketability of production. Depending on the type of crossbreeds (Buša, Simmental or Holstein Friesian), the production is highly variable, and is estimated to range from 2,000 to $4,000 \mathrm{~kg}$, with lactation in Buša and Simmental crossbred cows typically being shorter than the standard lactation and their total milk production lower (2,000-3,000 kg). In EU countries, which practice intensive cattle farming, apart from specialized dairy breeds (Holstein Friesian), other breeds are also significantly raised for milk production, such as Simmental, Brown Swiss, Montbeliard and Normandy, and the crosses are not further improved, but purebred selection is underway. Typical examples are Germany with an average of $6,776 \mathrm{~kg}$ per cow (Simmental cattle accounting for about $30 \%$ of the total cattle population in Germany), Austria with an average of $6,028 \mathrm{~kg}$ (Simmental cattle accounting for over $80 \%$ of the total cattle population in Austria), and France, where Holstein Friesian, Montbeliard, Simmental and Normandy breeds are used for milk production. The Simmental breed is mostly raised in the Republic of Srpska, as a breed combining different production traits (Perišić et al., 2009). Holstein Friesian is a high-yielding dairy cow in temperate climates. With good feeding and milking management, HF cows can yield more than $9,000 \mathrm{~kg} / \mathrm{cow} / 305$ day lactation period (Chandan et al., 2008).

The profitability of milk production on individual farms is mostly affected by feed costs which should be reduced as much as possible. One way to achieve this is through farm's own fodder production. Large areas of uncultivated and quality land open up the potential for the production of additional quantities of cheap feed and the ability to increase competitiveness. Besides price, calculations can 
result in other values, such as certain categories of costs, total costs, the market value of production, financial results, the level of labor productivity, the coefficient of efficiency, profitability level and others.

The aim of this research was to determine whether there are differences in production characteristics between Simmental and Holstein Friesian cattle breeds.

\section{Materials and methods}

To obtain a highly precise description of both dairy farm structure and the characteristics of dairy production systems, and to assess possibilities for improving milk production and farming conditions, survey-based research was conducted, targeting selected farms. The survey was carried out in the municipalities of Pale and Sokolac. The sample consisted of 30 farms including Holstein Friesian and Simmental cattle. The following characteristics were analyzed: number of household members, number of dairy cows in the herd, total land area, average annual milk yield per dairy cow, average milk fat content, protein content, and total annual production per dairy cow without premium. Data were analyzed using descriptive statistics for the specified characteristics. Measures of central tendency and measures of variation were used. The following indicators of variations were used: the minimum, the maximum, the variation interval, standard deviation and the coefficient of variation. Data were processed using methods applied in specific fields of research. Results are presented as tables.

\section{Results and Discussion}

Breeding of cattle having combined production traits on small farms housing a small number of animals is practiced under various moderately intensive conditions which are dominant on farms in the Republic of Srpska. Dairy cattle production has traditionally been one of the most important segments of livestock production in the Republic of Srpska.

Natural resources of the Republic of Srpska provide the following development opportunities: mountainous areas, combined ox type, meat-milk and meat types; lowland areas, type of cattle for milk production, milk-meat type, and fattening cattle for meat production (Table 1). 
Table 1. Production characteristics of cattle

\begin{tabular}{lllll}
\hline No. & Breed & $\begin{array}{l}\text { Breeding } \\
\text { target }\end{array}$ & Breeding principle & $\begin{array}{l}\text { Type of } \\
\text { production }\end{array}$ \\
\hline 1 & Simmental & $\begin{array}{l}\text { Milk-Meat or } \\
\text { Meat-Milk }\end{array}$ & $\begin{array}{l}\text { Pure-breeding, } \\
\text { possible crossing with } \\
\text { the red Holstein }\end{array}$ & $\begin{array}{l}\text { Breed for both } \\
\text { milk and meat } \\
\text { production }\end{array}$ \\
2 & $\begin{array}{l}\text { Holstein } \\
\text { Friesian }\end{array}$ & Milk & Pure-breeding & $\begin{array}{l}\text { Breed for milk } \\
\text { production }\end{array}$ \\
\hline
\end{tabular}

\section{Indicators of farm size}

Agricultural land is the basis for dealing with livestock production. In the Sarajevo - Romanija region, agricultural land covers 79,887 ha, accounting for $38.66 \%$ of the total area (Table 2).

Table 2. Indicators of descriptive statistics for the size of farms producing Holstein Friesian cattle

\begin{tabular}{lccc}
\hline Parameter & $\begin{array}{c}\text { Number of } \\
\text { members }\end{array}$ & $\begin{array}{c}\text { Number of heads/ } \\
\text { dairy cows }\end{array}$ & Land (ha) \\
\hline Min & 3.00 & 5.00 & 2.63 \\
Max & 11.00 & 12.00 & 40.63 \\
Variation interval & 8.00 & 7.00 & 37.99 \\
Average & 6.70 & 8.80 & 13.29 \\
Standard deviation & 2.21 & 2.30 & 11.38 \\
Coefficient of variation & 33.04 & 26.13 & 85.62 \\
\hline
\end{tabular}

Herd size of Holstein Friesian cattle farms ranges from 5-12, and the size of Simmental herds from 3-12. Standard deviation for Holstein-Friesian cattle farms is 2.30 , while variation for Simmental farms is 2.55 . Households differ in total land area, ranging from 2.63 to 40.63 (Table 2) and from 2.91 to 15.94 (Tables 3 and 4). 
Table 3. Indicators of descriptive statistics for the size of Simmental cattle farms

\begin{tabular}{lccc}
\hline Parameter & $\begin{array}{c}\text { Number of } \\
\text { members }\end{array}$ & $\begin{array}{c}\text { Number of heads/ } \\
\text { dairy cows }\end{array}$ & Land (ha) \\
\hline Min & 1.00 & 3.00 & 2.91 \\
Max & 7.00 & 12.00 & 15.94 \\
Variation interval & 6.00 & 9.00 & 13.03 \\
Average & 4.30 & 5.75 & 8.51 \\
Standard deviation & 1.75 & 2.55 & 3.58 \\
Coefficient of variation & 40.70 & 44.38 & 42.11 \\
\hline
\end{tabular}

Table 4. Indicators of descriptive statistics for the size of Holstein Friesian and Simmental cattle farms

\begin{tabular}{lccc}
\hline Parameter & $\begin{array}{c}\text { Number of } \\
\text { members }\end{array}$ & $\begin{array}{c}\text { Number of heads/ } \\
\text { dairy cows }\end{array}$ & Land (ha) \\
\hline Min & 1.00 & 3.00 & 2.63 \\
Max & 11.00 & 12.00 & 40.63 \\
Variation interval & 10.00 & $9-00$ & 37.99 \\
Average & 5.10 & 6.77 & 10.11 \\
Standard deviation & 2.20 & 2.84 & 7.34 \\
Coefficient of variation & 43.19 & 41.92 & 72.63 \\
\hline
\end{tabular}

\section{Indicators of productivity}

Indicators of productivity are shown in Tables 5, 6 and 7.

Table 5. Indicators of descriptive statistics for the production characteristics of Holstein Friesian cattle farms

\begin{tabular}{lcccc}
\hline Parameter & $\begin{array}{c}\text { Annual milk } \\
\text { yield per dairy } \\
\text { cow }\end{array}$ & $\begin{array}{c}\text { Average } \\
\text { mm }\end{array}$ & $\begin{array}{c}\text { Value of production } \\
\text { per cow (KM) }\end{array}$ & $\begin{array}{c}\text { Average } \\
\text { protein content }\end{array}$ \\
\hline Min & 4634.00 & 2.92 & 1645.00 & 2.29 \\
Max & 4987.00 & 3.35 & 1904.60 & 2.65 \\
Variation interval & 353.00 & 0.43 & 259.60 & 0.36 \\
Average & 4761.50 & 3.13 & 1791.19 & 2.51 \\
Standard deviation & 114.28 & 0.15 & 96.47 & 0.11 \\
CV & 2.40 & 4.76 & 5.39 & 4.27 \\
\hline
\end{tabular}


Table 6. Indicators of descriptive statistics for the production characteristics of Simmental cattle farms

\begin{tabular}{lcccc}
\hline Parameter & $\begin{array}{c}\text { Annual milk yield } \\
\text { per dairy cow }\end{array}$ & $\begin{array}{c}\text { Average } \\
\text { mm }\end{array}$ & $\begin{array}{c}\text { Value of production } \\
\text { per cow (KM) }\end{array}$ & $\begin{array}{c}\text { Average protein } \\
\text { content }\end{array}$ \\
\hline Min & 4239.00 & 3.08 & 1587.30 & 2.58 \\
Max & 4498.00 & 3.65 & 1970.12 & 3.13 \\
$\begin{array}{l}\text { Variation } \\
\text { interval }\end{array}$ & 259.00 & 0.57 & 382.82 & 0.55 \\
Average & 4372.90 & 3.35 & 1757.50 & 2.73 \\
$\begin{array}{l}\text { Standard } \\
\text { deviation }\end{array}$ & 86.72 & 0.16 & 114.75 & 0.14 \\
CV & 1.98 & 4.75 & 6.53 & 5.26 \\
\hline
\end{tabular}

Table 7. Indicators of descriptive statistics for the production characteristics of Holstein Friesian and Simmental cattle farms

\begin{tabular}{lcccc}
\hline Parameter & $\begin{array}{c}\text { Annual milk yield } \\
\text { per dairy cow }\end{array}$ & $\begin{array}{c}\text { Average } \\
\text { mm }\end{array}$ & $\begin{array}{c}\text { Value of production } \\
\text { per cow (KM) }\end{array}$ & $\begin{array}{c}\text { Average protein } \\
\text { content }\end{array}$ \\
\hline Min & 4239.00 & 2.92 & 1587.30 & 2.29 \\
Max & 4987.00 & 3.65 & 1970.12 & 3.13 \\
$\begin{array}{l}\text { Variation } \\
\text { interval }\end{array}$ & 748.00 & 0.73 & 382.82 & 0.84 \\
Average & 4502.43 & 3.28 & 1768.73 & 2.66 \\
$\begin{array}{l}\text { Standard } \\
\text { deviation }\end{array}$ & 209.03 & 0.18 & 108.52 & \\
CV & 4.64 & 5.61 & 6.14 & 0.17 \\
\hline
\end{tabular}

Variations in milk and milk yield depend on a range of factors, including genetics, stage of lactation, daily variation, type of diet, age, udder health and season, among others (Atil et al., 2001). According to Barnes et al (1990), in Switzerland, the milk production of Simmental cattle in 1999 was $5,502 \mathrm{~kg}$, with $4.02 \%$ fat and $3.28 \%$ protein. The average milk yield of Holstein Friesian cattle in Israel in 2004 was $11,200 \mathrm{~kg}$ per cow, 3.54\% fat and $3.08 \%$ protein (ICBA, 2004). Krupa et al. (2005) also found higher milk fat $(4.10 \%)$ and milk protein (3.35\%) percentages in Slovakian Pied cattle. Moreover, in three herds of Czech Fleckvieh cows, Wolfová et al. (2007) and Jílek et al. (2008) found milk fat percentage of $4.05 \%, 4.28 \%$ and $3.86 \%$, respectively, and milk protein percentage of $3.42 \%, 3.45 \%$ and $3.24 \%$, respectively. Low milk protein levels 
are frequent due to the low ration protein and/or energy level (Wolfová et al., 2007).

The average milk production in European countries for Simmental cattle is significantly higher than in the Sarajevo-Romanija region and the Republic of Srpska. Milk yield in Germany for Simmental breed in 1994 amounted to 5,404 liters (Fedderson et al., 1995) and in Switzerland 5,171 liters (Schimtz-Hsu, 1995). Simmental cattle in Slovenia makes up around $47 \%$ of the breed structure, and the average milk yield in 2006 was 5,340 liters (Cook et al., 2009). The average milk yield in 2007 in Serbia was 2,663 liters (Bozic et al., 2009), in Croatia 3,555 liters (Kovacic and Božić, 2009), in the Czech Republic 7,365 liters (Bosco et al. 2009) and in Poland 4,400 liters (Szajner, 2009). Chaunan and Hayes (1991) found a phenotypic correlation between milk production traits of Holstein Friesian cows. The relationship between milk production and milk fat was medium to very positive $0.73 \pm 0.004$, between content and yield of milk fat $0.38 \pm 0.007$, and the correlation between milk yield and fat content was negative $-0.31 \pm 0.007$.

\section{Conclusion}

The results suggest the following: slight variations in terms of production capacity between Simmental and Holstein-Friesian cattle were determined, indicating the homogeneity of conditions and production technology; Simmental cows had a higher percentage of butterfat, while milk production was higher in Holstein Friesian animals.

The main characteristics of the dairy sector in the Republic of Serbia at the primary level include small-scale production, especially in upland areas; low average yields on small-scale farms due to the fact that low productive crosses of different breeds are reared (used for milk and meat production), and high costs of production. Improvement in production parameters for small and medium-sized dairy farms can be achieved through quantitative genetic research. Genetic progress must be oriented to improving profitability by reducing production costs, specifically by increasing animal productivity. The use of sustainable milk production systems would increase milk yield and recover dairy cattle production.

\section{References}

Atil, H., Khattab, S. Yakupoglu, C., (2001). Genetic analyses for milk traits in different herds of Holstein Friesian cattle in Turkey. Journal of Biological Science, 1: 737-741. 
Barnes, M. A., Pearson, R. E., Lukes-Wilson, A. J (1990). Effects of milking frequency and selection for milk yield on productive efficiency of Holstein cow. Journal Dairy Science 73: 1603-1611.

Bogdanov, N., Božić, D. (2010). Review of agriculture and agricultural policy in Serbia. In: Agriculture in the Western Balkan Countries. Ed. Tina Volk, Leibniz. Institute of Agricultural Development in Central and Eastern Europe. Studies on the Agricultural and Food Sector in Central and Eastern Europe, Vol. 57: 189-218.

Bozic. D., Muncan. P., Sevarlic, M. (2009). An assessment of the competitiveness of the dairy food chain in Serbia. AgriPolicy, Enlargement Network for Agripolicy Analysis.

Chandan, R.C., Kilara, A., Shah, N. P. (2008). Dairy processing \& quality assurance: Wiley-Blackwell.

Chauhan, V. P. S., Hayes, J. F. (1991). Genetic parameters for first lactation milk production and composition traits for Holsteins using multivariate restricted maximum likelihood. J. Dairy Sci. 74: 603-610.

Feddersen E., Pauw R., Ditting K., Rossner M., Bell H. (1995). Rinderproductionin der bundeesrepublik Deutschlan, 1994, ADR.

Gabina, D. (2006). The future of sheep and goat production in Europe: prospects within the framework of new support regimes and market conditions. Small Ruminant Research, 62 (3): 159-165.

Jílek, F., Pytloun, P., Kubešová, M., Štípková, M., Bouška, J., Volek, J., Frelich, J., Rajmon, R. (2008). Relationships among body condition score, milk yield and reproduction in Czech Fleckvieh cows. Czech Journal of Animal Science, 53 (9): 357-367.

Krupa, E., Wolfová, M.,Peškovičová, D., Huba, J., Krupová, Z. (2005). Economic values of traits for Slovakian Pied cattle under different marketing strategies. Czech Journal of Animal Science, 50: 483-492.

Perišić, P., Skalicki, Z., Petrović, M. M., Bogdanović, V., RužićMuslić, D. (2009). Simmental cattle breed in different production systems. Biotechnology in Animal Husbandry 25 (5-6): 315-326.

Petrovic, P. M. (2007). Sustainable sheep breeding. Institute for Animal Husbandry, pp. 256. Belgrade.

Schimtz-Hsu F. (1997). Zuchwertschätzung Exterieur beim Schweizerischen Fleckvieh-zuchtverband. Radna grupa Exterieur, Grub.

Wolfová, M., Wolf, J., Kvapilík, J., Kica, J. (2007). Selection for profit in cattle: I. Economic weights for purebred dairy cattle in the Czech Republic. Journal of Dairy Science, 90 (5): 2442-2455. 


\title{
ANALIZA GOVEDARSKIH FARMI USMJERENIH NA PROIZVODNJU MLIJEKA
}

\author{
Tatjana Pandurević ${ }^{1}$, Milica Mojević ${ }^{1}$, Ivan Rankić ${ }^{1}$, \\ Bojana Ristanović ${ }^{2}$ \\ ${ }^{1}$ Univerzitet u Istočnom Sarajevu, Poljoprivredni fakultet, Vuk Karadžić 30, \\ Istočno Sarajevo, Bosna i Hercegovina (RS) \\ ${ }^{2}$ Univerzitet u Prištini, Poljoprivredni fakultet, Lešak, Srbija
}

\begin{abstract}
Rezime
Studija je provedena u opštinama Pale i Sokolac, analize su izvršene na 30 farmi. Uzorak se sastojao od 30 farmi simentalske i holštajn-frizijske rase. Analiziranje se odnosilo i na veličinu farmi, zemljišta i broj članova domaćinstva, kao i na prosječan sadržaj mliječne masti, proteina i ukupne vrijednosti proizvodnje mlijeka po muznom grlu. Dobijene su male varijacije, jer su isti klimatski uvjeti, kao i slična primjena tehnologije gajenja (držanja) i načina uzgoja muznih krava (muznih grla). Nešto veći udio mliječne masti vrijedno je pomenuti kod simentalske rase muznih grla, što je i njegova rasna karakteristika.
\end{abstract}

Ključne reči: Simentalska rasa, Holštajn-frizijska rasa, karakteristike stočarskih farmi. 